\title{
Some Remarks on the Anatomy of the Osmundaceae.
}

\author{
BY
}

\author{
D. T. GWYNNE-VAUGHAN, M.A., F.R.S.E., F.L.S. \\ Professor of Botany in Queen's University, Belfast.
}

With Plate XLIV and five Diagrams in the Text.

THE investigations that have given rise to this account were begun 1 with the intent of finding out whether any of the primitive features exhibited by certain fossil Fern stems assigned to the Osmundaceae by Dr. Kidston and myself ${ }^{1}$ were still retained in the young plants of the existing representatives of the order. Before they were completed, however, a full description of the anatomy of Osmunala cinnamomea was published by Professor J. H. Faull, ${ }^{2}$ with whose observations my own agree very closely. A short account of the facts in Osmunda regalis may still be justified, because I place an entirely different interpretation upon them to that advanced by Professor Faull, and in any case confirmation in a different species is not without value.

My observations were chiefly made upon serial microtome sections of sporelings of Osmunda regalis. A few sporelings of 0 . palustris and of a Todea were also examined, but without materially affecting the results.

The stem of the young sporeling curves round at once from its point of attachment to the prothallus into an obliquely erect position. The first leaf constantly departs from a point directly opposite to the foot, and the protoxylems of the diarch xylem of the first root lie in the plane running through the foot and the first leaf. The second leaf arises opposite to the first, but the subsequent leaves are arranged radially. In Osmunda cinnamomea, Faull found that the two-ranked arrangement is continued until the fifth or eighth leaf. He also discovered a cortical mycorhiza in the first roots of this plant which is not present in those of $O$. regalis.

Attention was especially directed to the effect of the departure of the

1 Kidston and Gwynne-Vaughan : On the Fossil Osmundaceae. Part I, Trans. Roy. Soc. Edin., vol. xlv, 1907, p. 759. Parts II and III, vol. xlvi, 1908-9, p. 2 I 3 , and p. 65I. Part IV, vol. xlvii, 1910, p. 455 .

${ }^{2}$ Faull: The Stele of Osmunda cinnamomea. Trans. Canadian Institute, vol. viii, I909, p. 5 I5.

[Annals of Botany, Vol. XXV. No. XCIX. July, 19u.] 
earlier leaf-traces upon the stele of the stem. It would, however, be unnecessary to give a detailed description of particular cases, owing to the close similarity with those described by Faull in Osmunda cimnamomea. An attempt was made to put together a generalized account, but it proved to be very difficult and unsatisfactory because the individual sporelings exhibit great diversity in their structure. In order to get over this difficulty, and at the same time to attain both brevity and clearness, a few diagrams have been constructed representing median longitudinal sections of characteristic cases. $^{1}$ In the diagrams the leaves are all supposed to arise in two opposite rows, but since they are really arranged radially it must be understood that the diagrams do not express all the facts as seen in the series of transverse sections from which they were constructed. The diagrams are not generalized conceptions, but each one is intended to represent at a glance, and as faithfully as possible, the nature and sequence of the events in a particular sporeling. If diagrams on the same plan be made from Professor Faull's descriptions, comparison with his results is greatly facilitated.

In every sporeling the first two leaf-traces departed in a perfectly protostelic manner, i.e. without leaving any depression in the xylem of the stem (Pl. XLIV, Figs. I and 2). The third leaf is nearly always protostelic, the fourth very often, and sometimes even the fifth (cf. the diagrams). Sooner or later, and sometimes as early as at the third leaf, the parenchyma of the xylem-sheath encroaches upon the xylem of the stem in the axil of the departing leaf-trace. In this way a groove or bay of parenchyma is formed which is prolonged downwards below the level of the departure to form a pocket (Fig. 3). The first parenchyma to appear in the solid xylem of the stem is often due to the formation of such a pocket (Diagrams I and 2). Just as often, however, the first parenchyma to appear is a true pith quite independent of the departure of the leaf-trace next above (Diagrams 3 and 4 ). It is continued past one or more leaf-trace departures without coming into relation with them even if they already have a pocket (Diagram 4). Cases also occur in which a pocket and a pith appear practically simultaneously (Diagram 5 and Fig. 3).

After the fifth or sixth leaf-trace the pith opens out into the xylemsheath bay above the axils of every trace forming the so-called medullary rays. Nevertheless, the pocket in the peripheral xylem is very often still formed, and is quite independent of the pith, from which it is separated by a flange of tracheae (Fig. 4). Sometimes this flange is short and the pocket opens out into the pith below the level of the leaf-trace. More often it reaches up to the level of the leaf-trace departure, and the pocket opens out into the medullary ray. Sometimes, again, it is prolonged for some distance above this level, and the pocket opens out into the xylem-sheath (cf. the diagrams).

1 In the diagrams the dotted area represents phloem and pericycle, the black xylem, and the white parenchyma. 

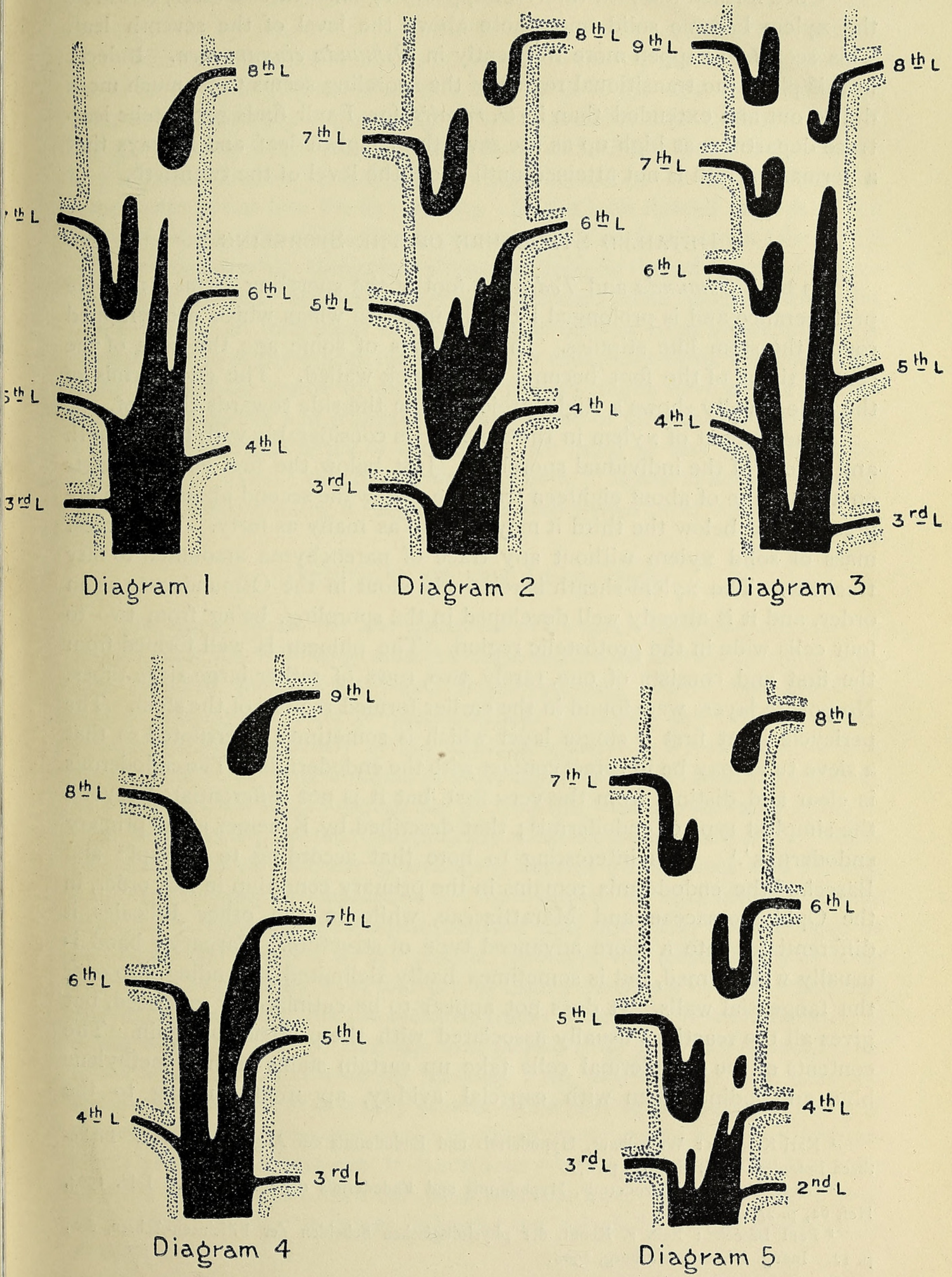
Once formed the pith rarely disappears again. In two cases, however, the xylem became solid once more above the level of the seventh leaf. This seems to happen more frequently in Osmunda cinnamomea. Indeed, in this plant the transitional region of the sporeling seems to be much more drawn out and extended than in O.regalis, for Faull finds protostelic leaftrace departures as high up as the seventh or eighth leaf, and he says that a permanent pith is not attained until about the level of the twentieth.

\section{Detailed Structure of the Sporeling.}

In both Osmunda and Todea the foot of the sporeling forms a massive protuberance and is prolonged laterally into two wings which are wrapped round the stem like stipules. In sporelings of some age the cells of the central tissue of the foot become quite thick-walled. The endodermis of the stele usually shows a slight projection on the side towards the foot.

The amount of xylem in the stele varies considerably with the strength and vigour of the individual sporeling. Just below the first leaf it consists on an average of about eighteen tracheae, below the second about $20-30$ are present, and below the third it may contain as many as forty. The largest mass of solid xylem without any trace of parenchyma amounted to fifty tracheae. The xylem-sheath is relatively stout in the Osmundaceae as an order, and it is already well developed in the sporeling, being from two to four cells wide in the protostelic region. The phloem is well formed from the first and consists of one, rarely two, rows of rather large sieve tubes. No porose layers were found in the earlier formed regions of the stem. The pericycle is at first a single layer which is sometimes interrupted so that a sieve tube may be in direct contact with the endodermis. The endodermis is clear and distinct from the very first, but it is not differentiated beyond the simplest type of endodermis ; that described by Kraemer as a 'primary endodermis'. ${ }^{1}$ It is interesting to note that according to Rumpf ${ }^{2}$ and Bäsecke ${ }^{3}$ the endodermis remains in the primary condition in this order, in the Ophioglossaceae and Marattiaceae, while in the other Filicales it differentiates into a more advanced type of structure. Caspary's band is usually well formed, but is sometimes badly delimited, extending also over the tangential walls. It does not appear to be cutinized or suberized, but gives all the reactions usually associated with the presence of lignin. The contents of the endodermal cells take up certain stains such as methylene blue and iodine green with especial avidity, apparently owing to the

${ }^{1}$ Karl Kraemer: Wurzelhaut, Hypodermis und Endodermis der Angiospermwurzel. Bibliotheca Botanica, I903, Heft 59, p. 87.

${ }^{2}$ Georg Rumpf : Rhizodermis, Hypodermis und Endodermis der Farnwurzel. Ibid. 1904, Heft 62, p. 25 .

$s$ Paul Bäsecke: Beit. z. Kennt. der physiologischen Scheiden c'er Filicineen-Achsen, \&c., p. I2. Inaug. Dissert., Marburg, I908. 
presence of some tannoid substance which acts as a mordant, for they are coloured blue by cupric acetate and reddish-brown by bichromate of potash.

Cells containing tannoid substances, and in consequence staining exactly the same as those of the endodermis, also occur in the very earliest formed pith, and at first sight might easily be taken as endodermal cells (Pl. XLIV, Fig. 5). They are scattered about irregularly and are also found in the medullary rays and in the xylem-sheath, both in the axil of the leaf-trace and for some distance out into the free petiole. In the later formed regions of the sporeling these cells are no longer present. The earliest formed cells of the pith are considerably elongated, almost as long as the tracheae, but above they soon become approximately isodiametric. The isodiametric cells, however, give no indication of having been derived from the septation of elongated cells in the apical meristem. No especially short tracheae were found towards the centre of the xylem, such as might have been expected from Thamnopteris and Zalesskya, either before or after the appearance of a pith. The cortical tissue of the stem is all more or less sclerotic below the first leaf. Above this level it consists of 4-7 layers of heavily sclerotic outer cortex surrounding a single layer of thin-walled inner cortex.

\section{STRUCTURE OF THE LEAF-TRACE.}

The size of the earlier leaf-traces varies so much from one seedling to another that the following must be regarded as an average account only. The xylem of the first leaf-traces is always very scanty and often no definite protoxylem could be distinguished. Probably the tracheae differentiated all simultaneously or else quite irregularly. Whenever a definite protoxylem could be determined in these small traces it was usually endarch. In a number of traces, however, the protoxylem was unmistakably mesarch (Fig. 5-8). In all, thirteen undoubtedly mesarch traces were found which belonged to seven different sporelings. Several other traces also showed a strong tendency to mesarchy. The majority of the mesarch traces belonged to leaves lying between the third and the sixth, two belonged to the second leaf and one to the eighth. Most of the mesarch traces' were fairly large, containing from fourteen to twenty tracheae, but two contained only eight tracheae. All the mesarch traces eventually became endarch if followed out far enough into the free petiole (Fig. 9). The mesarch condition sometimes continued all the way from the stele far out into the stipular leaf-base, or it was only present while passing through the cortex of the stem, or sometimes only in the basal region of the stipule. The mesarch traces are more or less oval in transverse section, and it should be noted that the departure of such a leaf-trace does not leave a pocket in the xylem of the stem because it is not hollowed out adaxially at the point of its departure. 
All the earliest leaves, even the very first, have fully developed stipules, and in the upper region of the stipule of the later leaves (from about the seventh or eighth) a conspicuous patch of protophloem is to be seen at each side of the leaf-trace on its abaxial surface. Three groups of mucilage sacs also appear in the same region of the stipule; one just outside each of the abovementioned protophloems and one median in the adaxial concavity of the trace. These features are characteristic of the stipular base of mature leaves, but they do not appear to occur in any part of the stipule of leaves below the sixth. The special tannin-containing cells that occur in the xylem-sheath of the leaf-trace in the base of the stipule of the early leaves have already been mentioned. It is to be noted that the xylem-sheath of the petiole of the fossil Bathypteris rhomboidea contains scattered sclerotic elements (Kidston and Gwynne-Vaughan, Part IV, Fig. 53).

\section{Discussion.}

The study of the sporelings of Osmunda regalis shows that in addition to and independent of the pithing of the stele, there is also a pocketing of the xylem-sheath in the axils of the leaves into the peripheral region of the xylem-ring. These xylem-sheath pockets account for the formation of the leaf-gaps or medullary rays in the originally continuous ring of xylem. In fact they break through the ring to meet the pith. In our paper on the Fossil Osmundaceae, Dr. Kidston and I did not fully appreciate the importance of the axillary pockets in the formation of the medullary rays. We regarded the medulary rays rather as directly due to the removal of the elements of the xylem-ring by their passage outwards into the departing trace, and we looked upon the pockets more as subsequent downward prolongations of the medullary rays into the xylem of the ring. I now regard the formation of xylem-sheath pockets as the initial cause of the medullary rays.

The interpretation of the vascular structure of the sporeling as indicating the succession of the stages passed through in the phylogeny of the race is by no means a simple straightforward matter, but is one that requires the greatest caution in its treatment. It seems to me that each new modification in a series of progressive changes in the evolution of any vascular system would appear first of all in the mature regions of the fully adult plant only, as a new and an additional stage in its ontogeny. If it may be held that the longer any given modification has been in existence in the race the earlier it will appear in the ontogeny of the individual, it follows, theoretically, that it will eventually appear as the earliest stage of the sporeling. This is only possible, however, if the stele of the sporeling is able to become bulky enough to express the modification in question. If it is not, there must be a lower limit to the downward penetration of the modification into the sporeling stem which will be determined by the minimum number of 
elements necessary for its physiologically effective construction. Below this limit the preceding stages will continue to exist undisturbed. If now a still later modification should arise requiring no more elements for its expression than the one immediately preceding it, it will eventually catch the latter up at its lower limit of penetration. There the two modifications will be superposed and may coexist, or, if their coexistence at the same level in the stem is impossible, the later modification will replace the earlier and eliminate it from the ontogeny altogether.

A series of modifications will appear in orderly succession in the sporeling stem only when the lapse of time has not yet been great enough for the successive stages to have caught each other up, or when each stage requires a successively increasing number of elements for its effective expression. Otherwise, in course of time the ontogeny will become telescoped and the sporeling will begin with the latest modification. In the case of a new modification that has caught up and overlapped its predecessor, the structure of the sporeling stele in this region will depend upon the effect of the superposition of the new modification upon the older one. This will vary according to the nature of the two modifications. They may be able to coexist without serious interference with each other at the same level in the stem, or the later one may so affect the earlier that it is no longer recognizable as such. Again, it is conceivable that a new modification should require even fewer elements for its expression than its predecessor. In this case it might pass by its predecessor and appear at a lower level in the sporeling than the really more primitive stage that phylogenetically preceded it, provided the latter is not deleted by the overlapping. All these and other factors still more obscure related to the special conditions of existence of the sporeling itself must, I believe, be taken into account when considering the phylogeny of the Osmundaceae in the light of the vascular structure of the sporeling. On these grounds the early appearance of the xylem-sheath pockets in the sporeling of Osmunda regalis is in no way incompatible with the true intrastelar nature of the pith. It seems clear that they are two entirely independent phenomena.

From this point of view also the criticism of the reduction theory put forward by Dr. Kidston and myself on the grounds of lack of sporeling evidence is not altogether valid. The term 'reduction' is taken to include simplification in structure consequent upon decrease in size, and it now seems to me that a sporeling could only be expected to provide evidence of such a reduction upon the supposition that it had an effect upon every stage in the plant's life. It is conceivable, however, that the reduction should only affect the later more complex stages in the development of a plant in such a manner that they are no longer formed. Such a reduction would be without influence upon the sporeling, which would still repeat the ascending series of changes up to the latest stage of reduction. 
From the above considerations, again, it is evident that the structure of the sporeling will not conclusively decide whether the pockets or the pith were the first to appear in the phylogeny of the Osmundaceae. Some facts bearing upon this question may be obtained from the fossil representatives of the order. In the first place Thamnopteris and Zalesskya, which have a solid xylem with a central mass of short thin-walled tracheae, show no trace of pocketing whatever. It must not be taken, however, that this fact excludes the possibility of the appearance of pockets before the formation of a pith. In both these genera the leaf-trace at its actual point of departure is rounded or elliptic in section, and it is easily seen that there would be no encouragement to form a pocket in the axil of a leaf-trace of such a form. The mesarch traces in the sporeling of Osmunda regalis are similar in section, and in this case also a pocket is never present. The formation of axillary pockets is clearly related to the departure of leaftraces which are adaxially concave at their very point of origin. If, indeed, such a thing ever existed as an Osmundaceous stem with a solid xylem and leaf-traces gutter-shaped at the very point of their departure, it is quite to be expected that there will also be xylem-sheath pockets in the periphery of its xylem. In Osmundites Dunlopi, the nature of the pith of which is unknown, the pockets are very small, and rarely, if ever, break the continuity of the xylem-ring. On the other hand, in Osmundites Kolbei, which has a mixed pith, the pockets are so deep that they break up the xylem-ring into separate strands. At the same time they are not so well developed as in the modern Osmundaceae, for the interruption of the xylem-ring is seldom completed at the actual level of the departure of the trace, but only at a point some distance above. ${ }^{1}$ It would appear, therefore, that the relative development of pithing and of pocketing was not uniform, but probably varied in different lines of evolution.

Two conclusions as to the nature of these nodal pockets are possible. The one that I would bring forward is that the xylem-sheath pockets are a relatively primitive feature in the order, and that they were primitively associated with protostelic leaf-traces, which departed without leaving a gap in the xylem-ring. Such protostelic departures with pockets are still to be found in the sporelings of Osmunda regalis and $O$. cinnamomea, and in the latter they sometimes even occur in adult plants. ${ }^{2}$ I have also described similar cases in Todea. ${ }^{3}$ The accuracy of this statement has since been called into question by $\mathrm{E}$. W. Sinnott. ${ }^{4} \mathrm{My}$ observations were made, it is true, from hand-cut sections and not from microtome series, but in the light of Faull's results I still venture to think they are correct.

1 Kidston and Gwynne-Vaughan, 1. c., Pt. IV, p. 459, Fig. 3.

${ }^{2}$ Faull, 1. c., pp. $5^{17} 7$ and 523 .

3 Kidston and Gwynne-Vaughan, Pt. I, p. 775.

4 Sinnott, E. W.: Foliar gaps in the Osmundaceae. Annals of Botany, vol. xxiv, 1910, p. 109. 
The other interpretation of the nodal pockets advanced by Faull ${ }^{1}$ is that they do not indicate a primitively gapless departure of the leaf-trace (cladosiphony), but a 'cladosiphony secondarily produced', and that they afford strong proofs of an evolution that tends towards cladosiphony. He holds that they owe their existence to an evolutionary tendency on the part of the xylem to increase in the direction of the pith. In fact, they are portions of the central ground tissue that have been closed in as a result of a centripetal proliferation of the xylem. As instances of this tendency to centripetal proliferation, Faull mentions cases in Osmunda cinnamomea in which he found xylem-strands of considerable size on the inside of the xylem-ring and separated from it by a varying amount of parenchyma ; also cases in which isolated tracheides, each surrounded by a ring of endodermal cells, occurred in the central ground tissue inside the internal endodermis. The latter he regards as having been 'pinched off' from the stele. If this is really the case they should be connected at some point with the main xylem-ring, and they would then have some analogy to the internal accessory strands in Dicksonia adiantoides and D. rubiginosa, and to me they would suggest an increase rather than a reduction of the vascular tissue in the stele. I consider all these cases to be very interesting, but I regard them as indicating a readiness on the part of the cells of a true pith to revert to the type of element from which they were derived, in fact, as partial reversions to a mixed pith. The existence of stems with a parenchymatous pith containing scattered tracheae, isolated or in groups, such as occur in the Lepidodendreae, Zygopterideae, and Osmundaceae, seems to me to be a very serious obstacle in the way of the acceptance of Professor Jeffrey's statement that all piths are extra-stelar. ${ }^{2}$ It is possible to account for them on the lines of this theory by using Faull's conception of a centripetal proliferation of the xylem into the enclosed extra-stelar ground tissue. But this is putting a heavy strain upon the idea and does not appear to me at all satisfactory. In particular, as regards the Osmundaceae, I find it difficult to reconcile a proliferation of xylem with the theory advocated by both Jeffrey and Faull, that the vascular system of this order has undergone a simplification of structure owing to reduction in size.

The Zygopterideae, again, present a further obstacle to those who deny the existence of a true intrastelar pith. For, so far as I am aware, no Zygopterid stem has yet been found with either a leaf-gap or a branch-gap in the stele, whereby the extra-stelar tissues could get in.

The presence of short relatively thin-walled tracheae occupying the position of a pith in Thamnopteris, Zalesskya, and Diplolabis Römeri, ${ }^{3}$ fits

1. c., p. $5^{2}+$.

2 Jeffrey : The Pteropsida. Botanical Gazette, vol. L, I9II, p. 40 I.

3 Gordon: On the structure and affinities of Diplolabis Römeri (Solms). Trans. Roy. Soc. Edin, vol. xlvii, I9I I, p. 7 I I. 
in well with the theory of the intrastelar origin of the pith in their respective orders, but would be meaningless if the pith be extra-stelar.

It is recognized that, if the Osmundaceous pith is intrastelar, the presence in the pith of an internal phloem in Osmundites skidegatensis and Osmunda cinnamomea and of an internal endodermis in Todea hymenophylloides has still to be accounted for, although this question may be taken as apart from, and as having no direct bearing upon, the intrastelar origin of the pith itself. As a matter of fact, several possibilities are open. In the first place Dr. Kidston and I have suggested that the phloem and endodermis may have been decurrent through the branch-gaps into the pith. It must be understood that the word 'decurrent' is here used in a special sense, and of course does not imply any actual motion. It is meant to imply that the stimulus to produce internal phloem and endodermis originated at the margins of a branch-gap, and phylogenetically was gradually transmitted to lower levels in the stem. To this idea Faull objects that he has found internal phloem in plants of Osmunda cinnamomea that have not yet branched. I do not see that this affects the question. If the internal phloem and endodermis in their present state of development are decurrent for some distance below the point of branching, the apical merlstem must form them in this region some time before it branches.

A second alternative, and a very probable one, is that the internal phloem and endodermis may have arisen entirely de novo in the intrastelar pith, and that subsequently connexions were established with the corresponding external tissues.

A third possibility is that some time after the formation of an intrastelar pith the outer phloem and endodermis were invaginated into the same through the leaf-gaps. Faull ${ }^{1}$ figures a case in Osmunda cinnamomea in which the two endoderms are in continuity through a leaf-gap. To me, however, his figure suggests that the internal endodermis has reached outwards to meet the external rather than vice versa.

As matters stand, however, it is in no way incumbent on a supporter of the intrastelar theory to pin his faith to any one of these suggestions.

The fossil evidence in the Osmundaceae I regard as distinctly in favour of the intrastelar nature of the pith, since it has brought to light Osmundites Dunlopi, the mixed pith in Osmundites Kolbei, and also the short tracheae in Thamnopteris and Zalesskya. Dr. Kidston and I believe that in Osmundites Dunlopi the pith is surrounded by an uninterrupted ring of xylem, but even if this be not so it would still represent an important transitional stage between a continuous ring and well-defined leaf-gaps which in any case must have existed. Both Faull and Sinnott have laid more stress upon the imperfection of this fossil than it really deserves, for in our description of it we have been far from lenient. It is true that the interpretation of fossil

$$
1 \text { 1. c., Fig. I I }
$$


structures is often to some extent a matter of personal opinion, and all that can be said is that, after making every allowance for lack of preservation, Dr. Kidston and I still adhere to our original statement, that 'if medullary rays actually were present in the living plant they must have been extremely narrow and very rare'.

As regards the lack of transitional forms, the supporters of the extrastelar pith theory in the Osmundaceae are very badly off indeed. As I understand it, they regard all the known forms, except those with solid protosteles, as stages in a series of reductions. In consequence they have not a single form to show of all the advancing stages that must have occurred from the first pocketing into the solid protostele up to the production of the perfectly dictyostelic form that is supposed to have antedated Osmundites skidegatensis.

As regards evidence of pocketing in the sporeling, I maintain that a distinction must be drawn between the pocketing of the peripheral tissues of the stele into the xylem and the pocketing of the external tissues of the stem into the stele. It is clear that the former must precede the latter. That the outer tissues of the stem have, in many cases, a tendency to invade the central tissues in the axils of the leaf-traces is well known, and these xylem-sheath pockets represent the initial and the simplest possible expression of this tendency. The next step is represented by the Lindsaya type of stele in which the phloem has followed the xylem-sheath, but the pocketing is still intrastelar. The simpler stages of extra-stelar pocketing are met with in certain Gleichenias and in Davallia pinnata, leading on to the formation of solenosteles and dictyosteles. Finally, even the epidermis and the surrounding atmosphere may join in the invasion and penetrate into the central tissues of the stem, as is shown in Onoclea, Cystopteris, and Aneimia. In the sporeling of Osmunda, however, there is no evidence whatever of the pocketing of the external ground tissue or of the endodermis into the stele. The xylem-sheath pockets are intrastelar and nothing else. It is only by first of all assuming that the reduction theory is true that they can be imagined even as indicating the position of previously existing extra-stelar leaf-gaps.

The arguments brought forward by Sinnott ${ }^{2}$ in favour of the primitive existence of leaf-gaps in the stele of the Osmundaceae based on the existence of gaps in the petiolar meristele made by the departure of the pinna-traces necessitate the acceptance of the preliminary assumption that the leaf is equivalent to an axial branch system. Even if this be granted, there is no reason to expect that the caulome and the phyllome should undergo the

1 Professor Faull (1. c., p. 530), referring to the presence of scale-leaves in Osmundites Dunlopi, represents us as admitting that this plant is reduced. This is obviously a misunderstanding. The scale-leaves occur in regular succeeding zones as they do in Osmunda regalis, and no doubt they served the same purpose of protecting the apex during adverse seasons. We do not regard either of these plants as reduced.

${ }^{2}$ 1. c., p. I 13. 
same evolutionary changes, but much to the contrary. No one, I take it, doubts the extra-vascular nature of the ground tissue in the concavity of the gutter-shaped leaf-trace. The way in which a leaf-trace originally elliptic in section becomes hollowed out adaxially is beautifully shown by that of Thamnopteris in its course through the cortex of the stem. ${ }^{1}$ This change in form is no doubt due to the bilaterality and dorsiventrality of the leaf as a whole, and can have nothing to do with the gaps made in the already gutter-shaped meristele by the far-away pinnae. Incidentally in the earlier leaves of the sporeling of Osmunda regalis the pinna-traces do not leave gaps of any kind. They are supplied by strands that are nipped off from the extremities of the already gutter-shaped meristele.

\section{SUMMARY.}

I. The early appearance of axillary pockets of xylem-sheath parenchyma in the xylem of the sporeling stele of Osmunda is confirmed.

2. The intrastelar origin of the pith in the Osmundaceae is adhered to.

3. The medullary rays are due to the breaking through of the xylemring by the xylem-sheath pockets, and are in consequence also intrastelar in origin.

4. The mesarchy found in the basal region of the leaf-trace in Thamnopteris and Zalesskya is still occasionally retained in the early leaves of Osmunda regalis.

\section{DESCRIPTION OF THE FIGURES IN PLATE XLIV.}

Illustrating Prof. Gwynne-Vaughan's paper on the Anatomy of the Osmundaceae.

Figs. I-4 are made from drawings, Fig. 5 from an untouched photograph, and Figs. $6-9$ from under-exposed prints used as camera lucida outlines. pocket.

Abbreviations : $l_{.} t_{0}=$ leaf-trace xylem; prx. $=$ protoxylem $; M_{0}=$ pith $; p k t .=x y l e m-$ sheath

Figs. I and 2. Osmunda regalis. Xylem of sporeling showing leaf-trace xylem departing in a protostelic manner. $\times 210$.

Fig. 3. Osmunda regalis. Xylem of sporeling showing simultaneous appearance of the pith and of a xylem-sheath pocket. $\times 210$.

Fig. 4. Osmunda regalis. Xylem of young stem; the xylem-sheath pocket on the left never comes into direct contact with the pith. $\times 130$.

Fig. 5. Osmunda regalis. Xylem of sporeling showing a mesarch leaf-trace and the tannincontaining cells in the early pith. $\times 150$.

Figs. 6,7 , and 8. Osmunda regalis. Meristeles of sporeling leaves with mesarch protoxylem. $\times 150$.

Fig. 9. Osmunda regalis. A mesarch leaf-trace becoming endarch. $\times \mathbf{I}_{5} \mathrm{O}$.

In the leaf-traces the adaxial side is towards the bottom of the page.

1 Gwynne-Vaughan: On the Origin of the Adaxially Curved Leaf-trace in the Filicales. Proc. Roy. Soc. Edin., vol. xxviii, Pt. VI, No. 29, I908, p. 433. 


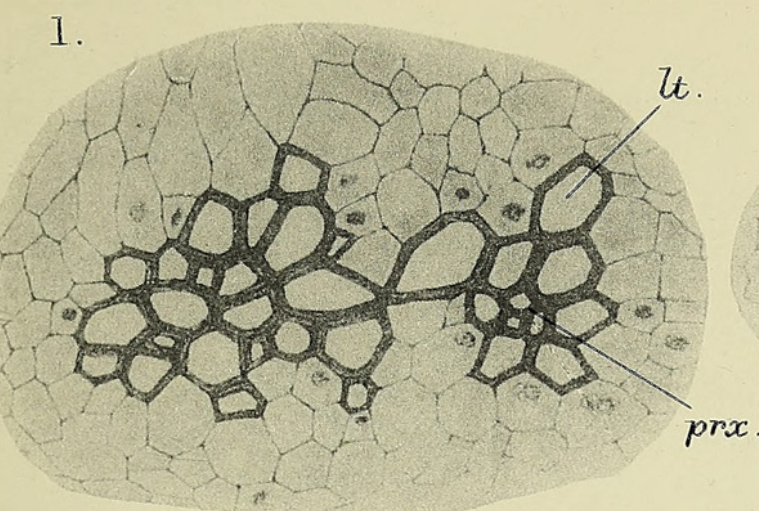

2.

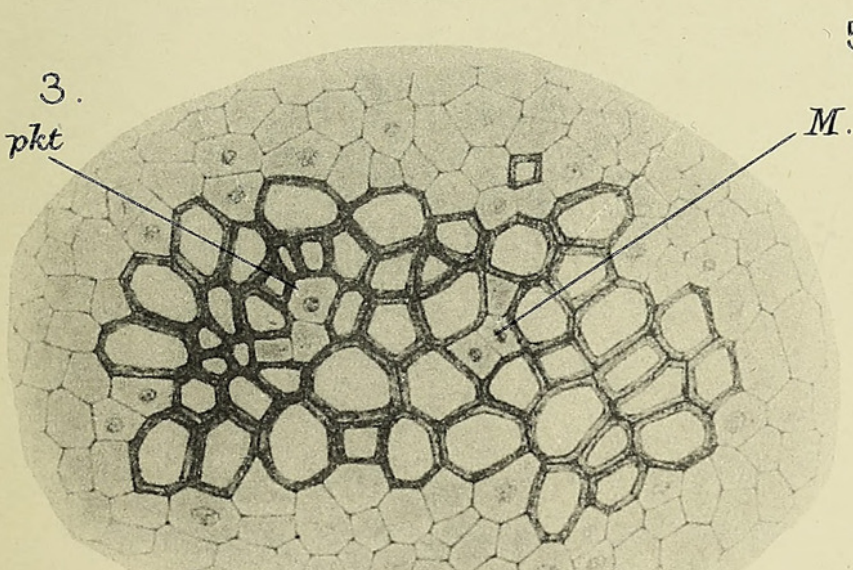

4.

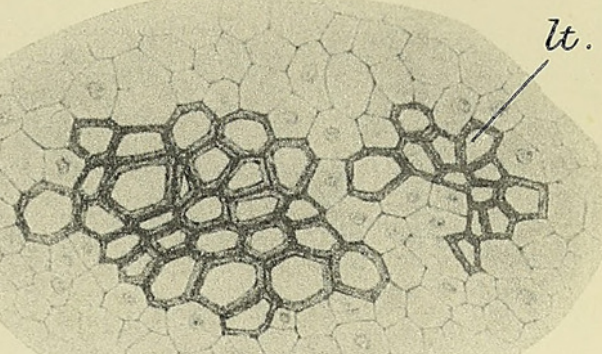

5.
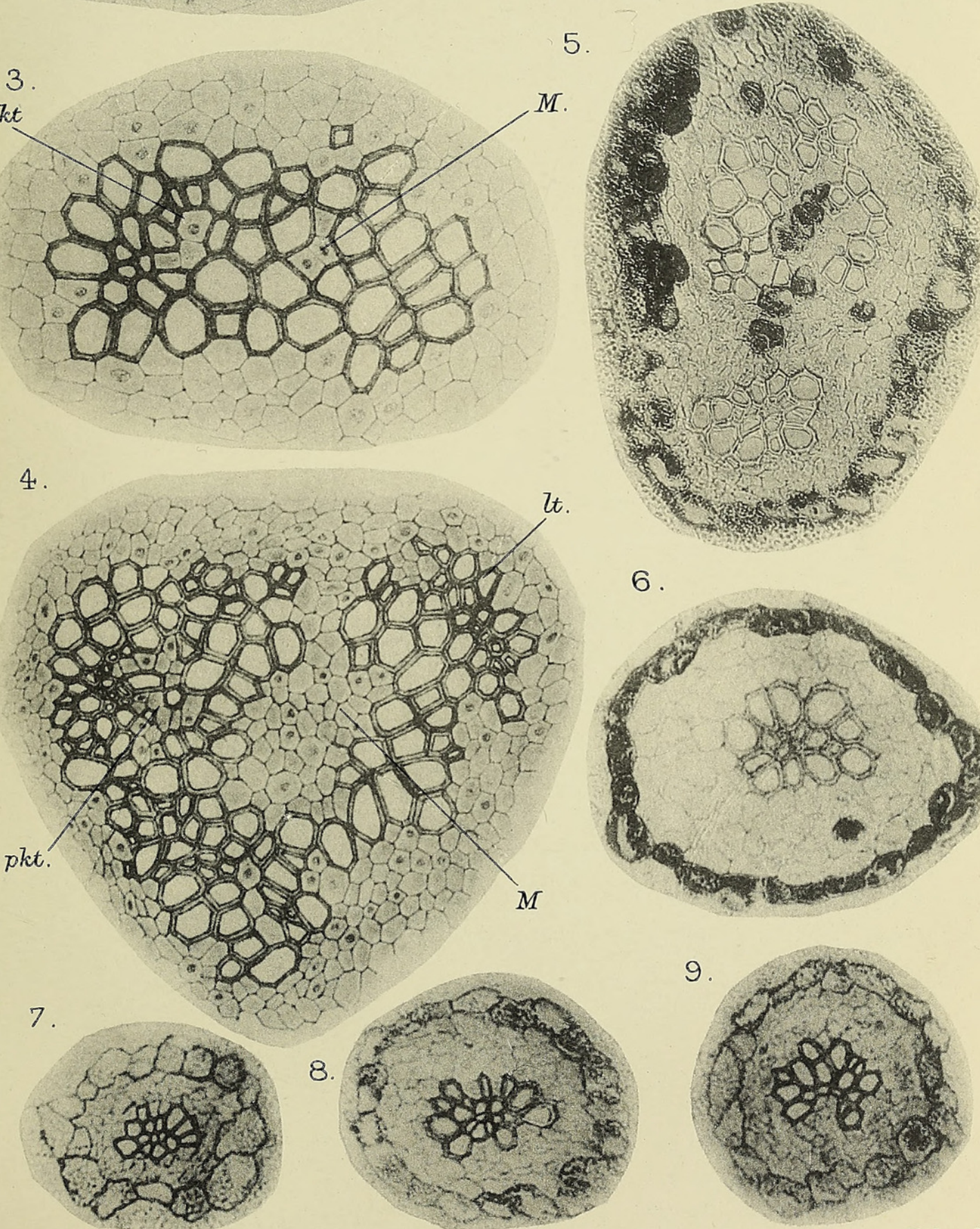

6.
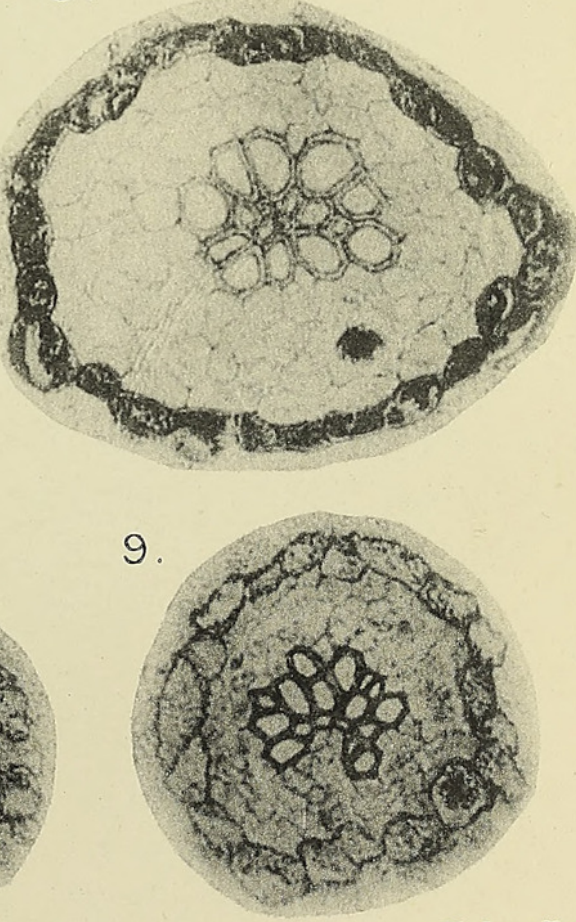

D.T.G.V. phot.

Huth coll

D.T. GWYNNE-VAUGHAN

OSMUNDA REGALIS. 


\section{$2 \mathrm{BHL}$ Biodiversity Heritage Library}

Gwynne-Vaughan, D. T. 1911. "Some remarks on the anatomy of the Osmundaceae." Annals of botany 25, 525-536.

https://doi.org/10.1093/oxfordjournals.aob.a089341.

View This Item Online: https://www.biodiversitylibrary.org/item/239487

DOI: https://doi.org/10.1093/oxfordjournals.aob.a089341

Permalink: https://www.biodiversitylibrary.org/partpdf/319849

\section{Holding Institution}

Smithsonian Libraries

\section{Sponsored by}

Biodiversity Heritage Library

\section{Copyright \& Reuse}

Copyright Status: Not in copyright. The BHL knows of no copyright restrictions on this item.

This document was created from content at the Biodiversity Heritage Library, the world's largest open access digital library for biodiversity literature and archives. Visit BHL at https://www.biodiversitylibrary.org. 